\title{
SOVIET FAMILY LAW IN THE LIGHT OF RUSSIAN HISTORY AND MARXIST THEORY
}

\author{
HAROLD J. BERMAN†
}

To maintain an equilibrium between change and continuity is a crucial problem for modern society, and one which has confronted Soviet Russia during the past decade in an acute form. The Revolution, which set out to annihilate everything that belonged to the past, has come to terms with the pre-revolutionary Russian heritage. If only to preserve the new, it has been found necessary to restore something of the old. And this, in turn, has involved a revaluation of the Marxist doctrines upon which the Revolution is founded.

Particularly in Soviet family law, there has been within the last 10 years a partial restoration of pre-revolutionary traditions and a partial restatement of Marxist principles. By investigating the backgrounds of Russian history and Marxist theory, we may be in a position properly to understand these developments.

\section{Pre-Revolutionary Russian Family Law}

The first written law of Russian history begins with the rules of the blood-feud. ${ }^{1}$ Such law testifies to a public order which existed, when it did exist, only as between families, but which was powerless to reach down into the internal relationships of a household. At best, it was inter-family law - analogous perhaps to our modern international law. Within the family there was only the law of that family, determined by tribal custom. ${ }^{2}$ The first Russian chronicle tells of incestuous marriage, wife-capture, general promiscuity. ${ }^{3}$ For the husband there was complete freedom of divorce, while the wife was not released from marriage even by the death of her husband but had to follow him into the next world. ${ }^{4}$

Into this primitive order of family life, the Eastern Orthodox Church

$\dagger$ Member, Third Year Class, Yale School of Law.

1. "If a man should kill a man, a brother may avenge a brother, or sons a father, or a father or the son of a brother or the son of a sister [may avenge] a son." Russkaia Pravda (11th century) Art. 1, cited in Goetz, 1 Das Russische Recht (1910) 6.

2. "In the ancient period of Russian history, the family, as everywhere, exercised autonomy. Personal and property relationships between members of the family were not subject to legislative determination. This circumstance explains the poverty of reference to family rights in historical and juridical documents." SHERSHENEvicH, 2 TEXTDOOK or Russian CiviL Law (11th ed. 1915) (in Russian) 302-3.

3. "The Radimichi and Viatichi and Severiane have the same custom, having wives in two's and three's, and so do the Krivichi and other Poganii, not observing the law of God but themselves creating their own law." The Chronicle of Nestor. See Kovulevsky,ModERN CUSTOMS AND ANCIENT Laws OF Russin (1891) 6-7.

4. SEERSHENEVich, op. cit. supra note 2. 
brought, in the eleventh and succeeding centuries, Byzantine Law, which was an integration of the Roman Law of Justinian and the canons of the Church. This fusion of imperial and ecclesiastical was carried over into Russian law. ${ }^{5}$

In the domain of family law, the legislation of Orthodox Russia strengthened marriage and gave it the significance of a sacrament. Polygamy was gradually eliminated. Wife-capture was replaced by the ecclesiastical form of marriage ceremony. ${ }^{\circ}$ Limits were set to freedom of divorce, and in the course of time were made equally applicable both to husband and wife. Gradually and slowly the influence of Christianity was extended over the whole people and the whole of family law. ${ }^{7}$ By the 19th century, however, there had been built around marriage and the family a mass of legal restrictions which, though designed to protect their sanctity, in fact threatened to stultify it.

Under the Imperial Russian Code of Laws, ${ }^{8}$ marriage and divorce

5. Emperor Leo the Isaurian, in the Ecloga (726 A.D.), reformed the lawis of Justinian (6th century A.D.) to conform with the laws of the Church, which had been formulated in 692 A.D. on the basis of the acts of the six great councils. The Ecloga, the first chapter of which deals with family law, was carried by the Eastern Church into Slavic lands, where it came to be considered as customary law, prevailing as ruling law in Bessarabia until June 1, 1928. Freshfield, Roman Law in the Later Rosian Earpire (1932) 23 et seq. Together with the Prochiron (c. 870 A.D.) and other later Byzantine codifications, the Ecloga was subsequently incorporated into the Russian ecclesiastical code (Kormchnis Kniga). As Byzantine imperial law was adopted by the Russian Church, so canon lav was adopted by the Russian state. Russkaia Pravda borrowed freely from ecclesiastical sources. See GoETz, op. cit. supra note 1 , at 239 et seq. And subsequently the Tsar, as "Protector" of the Church and head of the state, was responsible for the introduction of Christian principles into secular life.

6. The so-called Church Statute of Yaroslav, attributed to the 11th century, threatened with punishment "whoever carries off a virgin"; and "if a virgin refuses to take a husband and the father and mother give her by force," they were liable to criminal penalty.

7. Russian law never had the systematic character which marked the law of the West from the 11th and 12th centuries on. Before the 18th century, parish priests would often grant divorces at their own discretion, without reference to the official law of the Church. There are indications that for a long time people were being married without benefit of clergy, and there are traces of divorce by common consent down to the 17th century. Sse SHERSHENEVICH, op. cit. supra note 2, at 284. Likewise, in more recent times, despite the autocratic role of the Tsar, Russian law did not have the completeness or the binding force of Western law. It took centuries of effort before the countless diverse customs and statutes of Russia were brought together into a collection of any kind. When the Svod Zisosiov, or Code of Laws, of Imperial Russia was finally published in 1832, controversy raged for many years as to whether it had legislative force in and of itself or whether it was simply a collection of older rules which was binding only in so far as they were binding. See Vorus and Eliashevich, Civil Laws, A Practical and Theoretical Commentary (1913) (in Russian) 6. As late as 1877 it was observed by a French scholar that "of all the countries of Europe the Russian Empire is perhaps the one where the written law has the least absolute validity and remains the most often a dead letter." Legr, Élésents de Drorr CivIL Russe (1877) xi.

8. This was the Svod Zakovov, note 7 supra. Family law comprised the first part of the volume on civil law. It was called "the cornerstone of the civil law structure." Vorus and Elrashevich, op. cit. supra note 7, at 46 
were within the exclusive jurisdiction of the ecclesiastical courts of the various confesșions. A religious marriage ceremony was required for persons of Christian faith, and persons of other faiths had to celebrate their marriages in accordance with the customs or laws of their particular confession. ${ }^{9}$ Diversity of faith was a marriage impediment, ${ }^{10}$ as was a previous religious vow of celibacy. ${ }^{11}$ Marriage was prohibited between persons within the fourth degree of blood-relationship or the second degree of affinity as well as between persons related spiritually through godparentage. ${ }^{12}$ Persons over eighty were forbidden to marry, ${ }^{13}$ and members of the Russian Orthodox Church were forbidden to enter into a fourth marriage. ${ }^{14}$ Other marriage impediments were: absence of consent of the parties, ${ }^{15}$ insanity, ${ }^{16}$ an existing marriage not discontinued or dissolved by law, ${ }^{17}$ and nonage. ${ }^{18}$ Also, marriage was not permitted, though not rendered void if already performed, without consent of parents, guardians or trustees, and, in the case of persons in military or civil service, without the consent of their superior asserted in writing. ${ }^{19}$

Grounds for divorce likewise varied according to religious faith, and divorce actions were entirely within the jurisdiction of the ecclesiastical courts of the different confessions. ${ }^{20}$ For persons of Eastern Orthodox faith, divorce was permitted on grounds of adultery, impotence, criminal conviction with deprivation of civil rights, unexplained absence for five years, and the taking of monastic vows. ${ }^{21}$ Divorce for Roman

9. 10 Svod Zakonov (1914) pt. 1, Arts. 31, 61.

10. Marriages between Eastern Orthodox and Roman Catholics which were performed only by a Catholic priest were not valid until the marriage was also celebrated by an Orthodox priest. Id. Art. 72. Marriage was prohibited between members of the Eastern Orthodox or Roman Catholic Church and non-Christians, and between Protestants and pagans. $I d$. Arts. 37, n. 7, 85 .

11. Id. Arts. 2,37, n. 6 .

12. Id. Arts. 23,64 .

13. Id. Arts. 4, 37, n. 5. This dates from an edict of a synod of 1744 , at which the following reason was given: "Marriage is established by God for the increase of the human race, which is completely hopeless to expect from anyone eighty years old." Volfson, FaniLY LAw (1938) (in Russian) 39.

14. 10 Svod Zakonov (1914) pt. 1, Arts. 21,37, n. 5.

15. Id. Arts. 12, 26.

16. Id. Arts. 5, 62, n. 1.

17. Id. Arts. 20,37, n. 3,62 . This did not refer to persons whose religious doctrines permitted polygamy.

18. Id. Arts. 3, 63. The legal age was 18 for men, 16 for women. Marriages of persons under age could be confirmed by a special ceremony when the marital age was reached.

19. Id. Arts. 6, 9. It was not settled whether this applied to minors or to persons generally regardless of age. See Vorsis and EliasHevich, op. cit. supra note 7, at 104.

20. 10 Svod Zakonov (1914) pt. 1, Art. 46.

21. Id. Art. 56. 
Catholics was governed by Roman Canon Law. ${ }^{22}$ For Lutherans the grounds for divorce were relatively numerous; in addition to those admitted by the Orthodox Church, there were also included incurable, contagious and loathsome disease; insanity; debauched life and perverted vices; cruel and dangerous behavior; malicious abandonment; intent to deprive the other spouse of honor, life or freedom. ${ }^{23}$ Among non-Christians, in addition to the grounds permitted by the religious confession to which they belonged, there was added the conversion of one of the spouses to Christianity. ${ }^{2}$

The husband was given the dominant position in the family. The wife was obliged "to obey her husband as head of the family, to dwell with him in love, respect and unlimited obedience, to show him every compliance and attachment." ${ }^{25}$ In return, the husband was bound to support his wife according to his ability and "to love her as his own flesh, to live with her in concord, to respect her, to defend her, to forgive her inadequacies and to lighten her infirmities." 20 The unlimited obedience of the wife corresponded to the "unlimited power" $g$ of the husband. The wife took the husband's name, and he, as head of the household, had the right to select the domicile, and the wife was obliged to follow him. ${ }^{28}$ It was required that the spouses live together; ${ }^{9}$ in fact, all acts leading even to a voluntary separation were expressly prohibited..$^{30}$ Despite modification of this strict rule in judicial practice, ${ }^{31}$ it worked great hardship. Since she was bound to live with her spouse, the wife was not entitled, without his consent, to a separate passport under the Russian passport system, and hence could not get an independent job. ${ }^{32}$ This disability was partially removed by the Law of March 12, 1914, which permitted a separation from bed and board

22. Divorce was not permitted, but annulment could be granted, according to the law of the Roman Church, in cases of non-consummation of the marriage. SHERSHE:revicu, op. cit. supro note 2 , at 294-5.

23. Ibid.

24. 10 Svon Zakonov (1914) pt. 1, Arts. 79, 81, 82, 83. The petition for divorce could be brought only by the non-Christian spouse in the case of Jews, only by the converted spouse in the case of Mohammedans. A divorce on this ground would not lie for a Jew who became a convert to Lutheranism, since marriage between a Protestant and a Jew was compatible with the Lutheran faith.

25. Id. Art. 107.

26. Id. Art. 106.

27. Id. Art. 107.

28. Id. Art. 101.

29. Id. Art. 103.

30. Ibid. In each given case it had to be determined whether the separation tended to weaken the marriage. GullaEv, Russian Civn, Latw (4th ed. 1913) (in Russian) 514, n. 2.

31. See Shershenevich, op. cit. supra note 2, at 308-9.

32. This was especially hard for the working classes. "The rule is hard when the domicile of the husband is uncertain; it becomes shocking when it is made the object of extortion." Ibid. 
where cohabitation was unbearable. ${ }^{33}$ This gave the wife one weapon, at least, with which to combat an oppressive husband. Another weapon was her complete independence as a property owner. ${ }^{34}$ But the general predominance of power in the husband counteracted in large measure the extremely liberal property rights of women.

A hint of the legal relationship of children to their parents is given in the rule that "the wife is obliged primarily to obey the will of her spouse, although she is not freed by this from her obligations in regard to her parents." ${ }^{35}$ The Imperial Code also provided that parents had the right to choose for their children the kind of service or trade or other activity they were to enter. ${ }^{36}$ Regarding children born out of wedlock, a law of 1829 forbade their legitimation, though it is stated that this law always remained a dead letter. ${ }^{37}$ By a law of May 12, 1891 , legitimation by subsequent marriage of the mother and putative father was admitted, and a law of June 3,1902, replaced the term "illegitimate" with "born out of wedlock," and ameliorated the position of natural children in their relationship with their mothers, and, to a certain degree, with their fathers. ${ }^{38}$

The position of the wife and children in law was probably in advance of their general position in social and economic life. The chivalrous attitude toward women and love, which had developed in the West in the Middle Ages in a manner unique in history, reached Russia only in the time of Peter the Great, and then it was confined in its influence largely to the nobility and the upper classes. ${ }^{39}$ There is evidence of an

33. 10 Svod ZaKonov (1914) pt. 1, Art. 103, n. 1. The grounds upon which colabitation could be judged unbearable were: cruelty, dishonorable or vicious behavior, grievous insults, grievous mental or contagious physical disease, a disease of the wife rendering further cohabitation dangerous to her life or health, or a general breach of the duties pertaining to marriage.

34. Id., Arts. 109, 114-5. The spouses were specifically forbidden to interfere with each other's property though they could strengthen their estate by sale or gift to cach other on a general legal basis. Id., Art. 117. Also the surviving spouse had a right to an appointed share of the property of the deceased spouse. Id., Art. 1448. Neither was responsible for the debts of the other, but there was a presumption that the property belonged to the debtor spouse. GuliaEv, op. cit. supra note 30, at 520-1.

35. 10 Svod Zakonov (1914) pt. 1, Art. 108. For the control of parents over the marriage of their children, see supra pp. 4-5.

36. 10 Svod ZAKonov (1914) pt. 1, Art. 202. At 17, the children could appeal such a decision to the guardianship court. Id., Art. 204. In certain cases the parents could deprivo their children of their inheritance. Tiurtriumov, Crvil Law (1922) (in Russian) 421.

37. Eliachevitch, Nolde, Tager, 3 Traite de droit civil ET commercial des SOVIETS (1930) 284.

38. Shershenevich, op. cit. supra note 2, at 347-348.

39. Peter was responsible for many reforms in Russian family law. He pushed to the forefront, in marriage, the element of consent, ordaining that parents and masters must give their oath that they would not compel their children and serfs to enter into matrimony, and instructing the courts to prosecute the forcible seizure of women for marriage. Ho also deprived betrothal of its religious and property significance. Since the religious ceremony 
incipient Age of Chivalry at the end of the 12th century, which was cut off by the Mongol invasions. ${ }^{40}$ Certainly two centuries of the "Tartar yoke" could not but have stifled any movement in that direction. Under the influence of the Asiatic attitude toward women, the Russian nobility developed the institution of the terem, a special addition to the house in which the women were kept locked away. With the expulsion of the Mongols in the 15th century, and the rise of the Muscovy State, the position of women seems hardly to have improved. The Domostroi, or "household organization," written in the 16th century by a priest as a set of instructions for his son, depicts a family life in which the man is a despot who rules his wife and children with a whip. ${ }^{41}$ It is a mistake to give to such institutions as the terem or the -rules of the Domostroi a legal force, or to view them as evidences of the legal position of women. In fact, it was just during the era of the Domostroi when the common consent of the spouses was pushed forward as a sufficient ground for divorce. ${ }^{42}$ Also, throughout Russian history, individual women have exercised political power and prestige, ${ }^{43}$ and, especially in the 18th and 19th centuries, some women were large landholders, who, though they did not hold the franchise, could be personally represented as landholders in the zemstio (parliament).4 Nevertheless the terem and the Domostroi reflect a social attitude toward women, and it is significant that it is not until the 19th century that

is the constitutive act in Eastern Orthodox marriage, betrothal had been held to be binding. In 1702 Peter declared that betrothal should be concluded not earlier than sis weeks before the wedding and that the betrothed could separate within that time. This resulted eventually, in 1775, in the decision to combine the betrothal and marriage in one act. Under Peter the tendency also developed to give women equal rights with men in the granting of divorces. See Shershenevich, op. cit. supra note 2, at 289 et seq., 302 et seq.

40. This is a suggestion of Prof. G. Vernadsky of Yale University. The picture given in ElnetT, Historic Origin and Soclal Developarent of Fasity Llfe in Russia (1926) of the influence of Christianity in this respect is certainly one-sided to say the least. Her statements that "Byzantinism permeated ancient Russia with gloom and austerity" and that "the vow of abstinence and a denunciation of the world came to be considered necessary for every man who wanted to be a real Christian" give a distorted view of only one aspect of the Christian paradox. Id. at 22. The other aspect is expressed in the sacramental quality of marriage, and the divine ordinance of love between husband and wife. In the Instructions of Vladimir Monomach, ruler of Kiev in the 12th century, this higher conception of married love is expressed. It is an error to confuse the Byzantine world-view with that of Puritanism.

41. Careful regulations are given as to how and when to beat one's wife and children. See ELNETT, op. cit. supra note 40, at 34-5.

42. See note 7 supra.

43. One of the greatest rulers of the Kievan period of Russian history was Princess Olga (10th century). Empress Catherine II (18th century) is also a noteworthy example.

44. It is claimed by some that the independence of women as property-owners dates from ancient times. The better view seems to be that prior to the 18th century there was community of property, but with certain exceptions in favor of separation, and that in the 18 th century separation became the rule. See SeErsaenevice, op. cil. silpra note 2, at 302 et seg. 
one finds women glorified in literature and the love of women treated as a noble and enriching thing. Tatiana, in Pushkin's Eugene Onegin, and the women of Nekrassov's Russian Women were prototypes of the heroines of the nineteenth century Russian intelligentsia; they were symbols of a new personality, which became, ultimately, one of the elements of the Revolution. The Feminist movement of the 1860's also played an important part in the pre-revolutionary ferment. But in turning to Nekrassov's Who Can Be Happy and Free in Russia?, one gets a glimpse of the misery and oppression of women among the peasantry. ${ }^{45}$ In this respect, too, it must be remembered that Russia was predominantly a pre-industrial economy, and that most women were peasant wives and mothers, whose lot in any case was not a happy one. ${ }^{46}$

The pre-revolutionary Russian family was governed, then, by an ecclesiastical law which, in overcoming pre-Christian licentiousness and violence, and in emphasizing the sacramental quality of marriage and the family, had succeeded in giving to the Russian family a charter more liberal in many respects than that provided in European legislation generally; but which nevertheless prescribed severe impediments for entrance into marriage, strict rules of divorce, and heavy disabilities for wives and children. And outside the law, in social and economic life, women on the whole remained in a position of marked inferiority, amounting often to oppression and even enslavement.

\section{The Marxist Conception of Law and the Family}

Against this ancient heritage was brought to bear the impact of the Marxist conception of the family and law. ${ }^{47}$

45. For a literary portrayal of the excesses to which brutality to children could go, sco Dostoevsky, The Brothers Karamazov (Modern Library ed.) 282 el seq. Professor Ernest Simmons of the Russian Institute of Columbia University has stated that Dostoevslyy found these examples in newspapers and other reports and that they were presumably true stories.

46. Of the economic position of independent working women, according to the census of 1897, 55 per cent worked as domestic servants, and 25 per cent as farmhands. ERDE, Marriage aNd the Family in the U.S.S.R. (Soviet Booklets, No. 2, 1943) 8. See note 143 infra:

47. It is important to note, however, that Marxism grew out of, and reacted against, a different culture from that of the Russia to which it was applied by the Bolsheviks. In Europe both law and the family had developed, since the eleventh century schism between the Eastern and Western Church, along different principles, though from the same founda* tions. That marriage is a sacrament, and the family of divine institution-is the common Christian heritage of both East and West. But under the influence of the Papal Revolution of 1076, with its organization of the Western Church into a visible political unit entirely separate from any secular state, and its sponsorship of a renovated canon law systematic in character and independent of the rulers of this world-under the influence of this (from the Eastern Orthodox point of view) dualistic and legalistic conception of Church and State, God and Man, spiritual and secular-the conception of sacraments itself changed radically. See Rosenstock-Huessx, Out of Revolution: AutobiograpHy of WESTERN MAN (1938) 
In the philosophy of Marx and Engels, the family is a historical institution whose development is to be explained in terms of economic forces rather than of divine ordinances. Engels ${ }^{45}$ turned to anthropology to seek the origin of the family, ${ }^{49}$ tracing it from savagery and barbarism through the various stages of civilization (slave, feudal, bourgeois). According to his scheme, ${ }^{50}$ in the stage of savagery there was, first, promiscuity of sex life, every woman belonging to every man and every man to every woman. From this there developed the consanguine family, in which the marriage groups were ranked according to generations. The first advance in organization was the exclusion of parents and children from mutual sex relations; later came the exclu-

c. 10; Rome: The Rerolution of the Holy See. See also Somr, D.1S ArTKatHoLIsche KincresRECHT UND DAS DERRET GratlaNs (1918). In Russian Orthodosy, the word for sacrament is tainstio, mystery, and anything is capable of becoming a sacrament; the number of mysteries is unlimited. But Gratian and the twelfth and thirteenth century canonists reduced the number of sacraments to seven, and surrounded them with a whole body of legal principles and legal procedure. Although in 18th century Russia there was, under Western influence, a similar reduction of sacraments to seven, these were held to be merely the seven most important, and others were not excluded. Thus, just as Russia did not share in the romantic movement which swept Europe in the Age of Chivalry of the 12th and 13th centuries (see p. 30 supra), she also did not share in the contemporaneous movement within the Roman Catholic Church which separated Church and State and reduced the marriage sacrament to law-a movement against which the Age of Chivalry itself may have been a reaction. Russian law never assumed the systematic and definitive character of Western law. See note 7 supra. In the West, under the influence of a Roman and Canon law which had not come down through the later Byzantine Empire and Eastern Orthodoxy but had mether been adapted directly from Justinian by the twelfth century Roman Catholic Romanists and Canonists - there was from that time on one official and exhaustive legal code of marriage laws, enforceable in the medieval ecclesiastical courts and subsequently inherited by the secular courts in Protestant lands. Protestantism modified Catholic family law-which itself changed under the influence of the Counter-Reformation; but the essential distinction between Eastern and Western doctrines remained. The West, whether Catholic or Protestant, conceived the family to be bound by certain unchangeable moral principles ordained by God to be fixed by law. In contrast to the more or less haphazard development of juridical concepts of the family in Russia, European society had a 700-year-old tradition of strict legal doctrines of family life. It was against this legalism and moralism that Marxand Engels rebelled.

For a Roman Catholic criticism of the Marxist theory of the family, see Asicel, MarxISME ET FAMmle (1938). For a Russian Orthodox criticism of Catholic dogmatism, see Bulgakov, The Orthodox Church (1935) 203.

48. Engels, The Origin of the Fanuy, Private Property axd the State, Ix the Light of the Researches of Lewis H. MorGaN (4th ed. 1891), first German edition 1884. This work is the main source of Marxist doctrines of the family, and is still cited at length in Soviet textbooks on family law as well as in much Soviet legislation.

49. Engels takes his anthropology from the contemporary American anthropologist Lewis Morgan, whom he describes as "the first person with expert lnowledge to attempt to introduce a definite order in the study of the history of primitive man." Id, at 19. MIorgan's conclusions are not generally accepted by modern American anthropologists, though it is recognized that he made a great contribution in his time.

50. Id. at 27 et seq. 
sion of brothers and sisters; finally the prohibition of marriage between cousins. But there was still, under this system, group marriage, and therefore descent could only be traced on the maternal side. Eventually the descendants of a common ancestress came to form a gens, which was a rigidly limited circle of blood relations in the female line who were not allowed to marry one another. With the development of the pairing family in the next stage of primitive society (barbarism), the household was still communistic, as was the gens, which now ruled the tribe. The pairing family, which was based on the temporary cohabitation of one man with one woman, was the end result of primitive development.

But "new social driving forces" 51 came into operation, which compelled a new form of the family to arise out of the pairing family. A pastoral economy replaced hunting. The herds of domestic animals became the private property of the family chiefs. And with the institution of slavery, another form of private property developed. This accumulation of wealth gave the man a more important status in the family than the woman; further, it created a stimulus for him to overthrow the established order of inheritance in favor of his own children. Thus descent and the right of inheritance through the female line was overthrown, and male lineage and right of inheritance from the father instituted. ${ }^{52}$ The woman was degraded, enslaved, made a mere instrument for breeding children..$^{53}$ The patriarchal family emerged.

It was a short step from patriarchal polygamy and the absolute command of men over female slaves-which was the transition stage from barbarism to civilization-to patriarchal monogamy as civilization has known it, i.e., the monogamy of the wife with the secret polygamy (in the form of adultery and prostitution) of the husband. ${ }^{44}$

Civilized monogamy, then, in Engels' philosophy, emerged with private property and the desire of the father to pass his estate on to his own children. It was a means of subjection of one sex by the other, and appeared, significantly, at the same time as the first class oppression, that of slaves by their masters. Through the successive stages of civilization, as viewed by Marxism, the family has served to protect the ruling class in its control of property.

But what of the future? "We are now approaching a social revolution in which the hitherto existing economic foundations of monogamy will disappear, just as certainly as will those of its adjunct, prostitution. . . . By transforming at least the greater part of permanent

51. Id. at 45 .

52. Id. at $46-7$.

53. "In order to guarantee the fidelity of the wife, that is, the paternity of the children, the woman is placed absolutely in the man's power; if he kills her, he is but exercising his right." Id. at 48 .

54. Id. at 51 et seq. "Actually, for men, group marriage exists to this day." Id. at 61. 
heritable wealth-the means of production-into social property . . . [the revolution] will reduce all this anxiety about inheritance to a minimum. Since monogamy arose out of economic causes, will it disappear when these causes disappear? One may not unjustly answer: far from disappearing, it will, indeed, begin to be completely realized. For with the conversion of the means of production into social property, wage-labor, the proletariat, also disappears, and therewith also the necessity for a certain - statistically calculable-number of women to surrender themselves for money. Prostitution disappears; monogamy, instead of declining, finally becomes a reality-for the men as well." :

Monogamous marriage in a proletarian society will be based more on love than on economic considerations. The supremacy of men will not survive the emancipation of women and "the re-introduction of the entire female sex into industry." "so And the indissolubility of marriage will disappear, since this is partly the result of the economic conditions under which monogamy arose and partly an outworn religious tradition. ${ }^{57}$ The individual family will be abolished as the economic unit of society; as a non-economic unit, its nature will be determined by the public opinion of a new generation freed from economic fear. ${ }^{63}$

Like the family, the state, in Engels' view, ${ }^{59}$ emerged in history with the rise of classes. Its first function was the protection of the private property of the monogamous family against the communistic tribal gens and the oppressed slaves. Throughout history, the role of the state has been that of an instrument of class repression. But with the achievement of a classless society, the state will gradually become superfluous. ${ }^{60}$ The government of persons will be replaced by the administration of things and the direction of the processes of production. In Engels' famous words, "the state is not 'abolished', it withers away." 61

The Soriet Restatement of Maraism. It was with the weapon of Marxist historical relativism and economic determinism, a weapon that had been forged in the fires of a disintegrating European legalism and moralism, ${ }^{62}$ that Soviet jurists in 1917 attacked the family law of the Imperial Russian Code. ${ }^{63}$ Their aim was to smash the pre-revolutionary

\footnotetext{
55. Id. at $88-9$.

56. Id. at 61 .

57. Id. at 68 .

58. Ibid.

59. Id. at 64 et seg.

60. Ibid. See also ENgels, ANTI-Duenring (English ed. 1934) 308.

61. Ibid.

62. See note 47 supra.

63. Despite efforts of the leaders against it, anarchism of the Balkunin variety mas rife during the early years of the Revolution. To such may perhaps be attributed such extreme views as those of Alexandra Kollontai, who stated that "the family is ceasing to be a necessity both for its members and for the state." KollonTaI, Cospronzsus AND TIE FA:mLY
} 
conceptions entirely. In their enthusiasm many of them went beyond Marx and Engels and preached the withering away not only of the state but of law and the family as well.

It was visualized ${ }^{64}$ that the family as a juridical entity would disappear. In a Communist society there would not be the slightest need for the state to mix into marital affairs. The abolition of marriage would not be a matter of decree; rather, in time, it would simply become a reality. "Already," it was stated in 1925, "the Soviet power has freed it from any superfluous shackles, has eliminated from it all religious and ecclesiastical survivals. ... Marriage in Soviet legislation has ceased to be a prison . . . , a union lifelong in principle, concluded for a whole lifetime, indissoluble." 65 And already a program had been begun for the bringing up of all children by the state. ${ }^{66}$

The doctrine of "the withering away of the law in general, that is the gradual disappearance of the juridical element from human relations" 67 was the official jurisprudence, expounded by the most prominent legal writers. ${ }^{68}$ "The withering away of the categories of bourgeois law-the categories themselves, and not this or that particular rulecan under no circumstances mean their replacement by some new categories of proletarian law," wrote Pashukanis. ${ }^{69}$ It was expected that, as Engels had vaguely suggested, ${ }^{70}$ administration would replace law. Thus establishment in 1918 of a Civil Registry Bureau for registration of marriage, divorce, births, etc., was hailed as a step in the right direction. "Here we get a glimpse of a governmental function which is

(1920) 9. The chapter headings of this small pamphlet are sufficient to reveal the spirit of the time: "30,000,000 Women Bearing a Double Burden," "Workers Learn to Exist Without Family Life," "Household Work Ceasing to be a Necessity," "The Married Woman and the Factory," "The Dawn of Collective Housekeeping," "The Child and the Communist State," "The Mother's Life Assured," "Marriage No Longer a Chain," "The Family a Union of Affection and Comradeship," "No More Prostitution," "Social Equality of Men and Women."

64. See Golkhbarg, Comparative Family Law (1925) (in Russian) 184-6. Goikhbarg was editor-in-chief of the Collegium of Laws and played a preponderant part in drawing up the first Family Code.

65. Ibid.

66. Ibid. See note 165 infra.

67. Pashukanis, General Theory of Law and Marxisim (3d ed. 1927) (in Russian) 104.

68. Pashukanis, the leader of this school of thought, was Director of the Institute of Soviet Organization and Law of the Academy of Science and editor of Soviet State and Law.

69. PAsHukAnis, op. cit. supra note 67 at 22. See GoIkHBARg, 2 Economic LAw (3d ed. 1924) (in Russian) 8, 19: "We refuse to see in law an idea useful for the working class. ... Religion and law are ideologies of the exploiting classes, and the latter gradually took the place of the former. . . At the present time we have to combat the juridical ideology even more than the religious."

70. See supra p. 35; Golkhbarg, Proletariat and Law (1919) (in Russian) 12: "The temple of bourgeois power is legislation and its fetish is the statute; the temple of the proletarian and socialist world order is administration and its divine worship is labor." 
statistical and informative rather than magisterial and repressive. ... In this tentative form we see the beginning of an important function in the computation and appraisement of social statistics which will survive and achieve its highest place in a society which sincerely appreciates and can use such knowledge." 71

In the middle of the last decade, Soviet jurisprudence underwent a profound upheaval. The crisis took the form of an attack on the theories of Pashukanis, Stuchka, Krylenko, Goikhbarg, Rubinshtein, and other erstwhile distinguished jurists, for their negative and "nihilistic" attitude toward law. ${ }^{72}$ The repercussions were felt and are still being felt in every field of Soviet law. ${ }^{73}$

The new jurisprudence emphasizes the positive role of law in the building of Socialism. This attitude was expressed most forcefully by Vyshinsky, who replaced Krylenko in 1937 as People's Commissar of Justice. ${ }^{74}$ Vyshinsky stressed the rights of the individual, called for a reconstruction of civil law, and vigorously defended family law and the law of testamentary succession. He attacked the Pashukanis school for reducing law to politics, saying that "such a way of thinking reflects discredit on Soviet law and legality by asserting that the Soviets do not defend the rights of citizens but tend to carry out their politics." 75 He likewise attacked Stuchka and his followers, who, by reducing law to economics, "fell into economic materialism," 70 "liquidated law as a particular and specific social category, drowned it in economics and deprived it of its active and creative role. Such a legal approach deprives the independent investigation of law as a special science of all meaning." 77 "To the students, the growing cadres, a nihilistic attitude toward Soviet Law was suggested." is "The enemies of the people

71. Cited in Russian Soviet Governarent Bureau, Tue Miarrage Laws of Sovet Russia (1921) 9-10.

72. See Hazard, Housecleaning in Soviet Law (1938) 1 Au. Q. ON THE Sovier UNoN 1; J. N. H. and W. S. R., Correcting Misinterpretations of Socieb Law, Preliminary Memorandum, 1937 (Yale Law Library); Schlesinger, Recent Dexelopments in Soriel Legal Tiseory (1942) 6 MOD. LAw Rev. 21; Schlesisger, Soviet Legal Theory (1945) 200 et seq.; Timasheff, The Crisis in the Marxian Theory of Law, Contemporary Law Pamphlets, New York University School of Law, Ser. 2, No. 1 (1939).

73. See Hazard, Reforming Soviet Criminal Law (1938) 29 J. of Aus. INST. of Crus. L. AND Crnumology 157; Hazard, Cleansing Soriet International Law of Anti-Afarrist Theories (1938) 32 Axr. J. INT. L. 244.

74. See especially Vyshinsky, Basic Tasks of the Science of Soviet Socmalst Lati (1938) (in Russian).

75. Id. at 31. See Denisov, Soviet Public Law (1940) (in Russian) 79: "It is impossible to place law in opposition to politics, as it is impossible to identify law with politics. The identification of law with politics leads to a nihilistic attitude to law, to the dissolving of law in politics, to the ignoring of the role and significance of law."

76. Vyshinsky, op. cit. supra note 74 , at 31 .

77. Id, at 32 .

78. Vyshinskx, On the Situation of the Front of Legal Theory (1937) 5 Soculisr LEGaLITY (in Russian) 31 . 
slanderously asserted that Soviet law is not Socialist law, that in general there is not and cannot be Socialist law, that Soviet law is doomed to fade out and 'wither away,' " declared Vyshinsky. ${ }^{79}$

Passages are now found in the writings of Marx and Lenin to prove that their attack on law was an attack on bourgeois law and not a denial of Socialist law, and the attack on the family was likewise an attack on the bourgeois family but not a rejection of the family under Socialism. The situations which were faced in the 19th century and in the first two decades of the Revolution, are distinguished from the situation of today, in which, it is claimed, Socialism is achieved and the direct transition to Communism is under way. ${ }^{80}$

A "rehabilitation of law" ${ }^{11}$ has been carried out on a large scale. All law schools have been reestablished, and special law schools added. Instead of the more sociological and less strict economic public law, which had been stressed by Pashukanis, traditional civil law has been restored both in legislation and in university education. The importance of civil and criminal procedure and of the rights of the person ${ }^{82}$ has been stressed as against the earlier chaos of "revolutionary legal consciousness." Professors of law who were trained under the prerevolutionary regime have been invited to cooperate. ${ }^{83}$ Even the Latin language has been restored to a place of importance. ${ }^{84}$ "Judicial culture" and the need for "judicial authority" are emphasized. ${ }^{86}$

79. Vyshinsky, The Soviet Court and Soctalist Aduinistration of Justice (1938) (in Russian) 4.

80. Stalin has said that even the doctrine of the withering away of the state does not apply when there is "Socialism in one land" and that land confronted with "capitalist en. circlement"; that even if Russia attains pure Communism under such circumstances, it is doubtful whether the state could be weakened; and further, that "it would be ridiculous to expect that the classical Marxist writers should have elaborated for our benefit ready-mado solutions for each and every theoretical problem that might arise in any particular country fifty. or one hundred years afterwards. . . " See Stalin, Frou Socialisu to Communisu in the Soviet Union, Report to the Eighteentri Congress of the C.P.S.U. (B.), MARCH 10, 1939 (1939) 53 et seq.

81. See Laserson, Russia and the Western WorLd (1945) c. 4.

82. VYSHINSKY, op. cit. supra note 74, at 32, attacked Professor Yovtikhicv, who "dared to assert that the rights of the person play a rather subordinate role in the Soviet Republics by comparison with the rights of collective bodies."

83. Vyshinsky, supra note 78, at 58, speaks of "those honest jurists who, being educated to and penetrated by old legal culture and science, have shown themselves unable, just because of their weak Marxist-Leninist preparation, to resist the saboteurs efficiently."

84. See Gromov, On the Question of the Teaching of the Latin Language in Law Schools (1939) 3 SocraLIST LEGALITY (in Russian) 74. Recent textbooks have returned to the use of Latin legal terminology. This has particular importance in view of the fact that Russian law has historical roots in Roman Law. Previously, the use of Latin had been disparaged as a symbol of juridical formality.

85. "The work of the court acquires its greatest significance in that which may bo characterized as judicial culture. Questions of conduct of jurors, the organization of the judicial inquest; the order, forms and methods of the examination of witnesses, experts, 
And in the field of family law, the theories of the withering away of the family and of the transfer of authority over children from the parents to the state are identified with Trotskyism and fascism. "To "The task of Soviet Socialist family law," it is now stated, "consists in giving form to the new Socialist family and strengthening it in every way."

\section{Fundamental Principles of Soviet Family Law}

A study of Soviet family legislation from 1917 to the present, especially in the light of new decrees of 1944 and 1945, shows that the restoration of certain pre-revolutionary values concerning law and the family has been achieved without giving up important social ideals for which the Revolution has consistently stood.

The Decrees on Marriage and Divorce of December 18 and 19, 1917,83 (secularizing marriage and granting complete freedom of divorce) and the Family Code of $1918^{89}$ were designed to break completely with the religious principles of pre-revolutionary family law.co Moreover, the 1917 and 1918 legislation was intended to be only a temporary beginning, ${ }^{91}$ a paving of the way for the transformation of the family into a free association, bound not by law but only by the free will of the members. These developments reached their climax in the new Family

defendants; the place which the court can secure in the judicial process for the defense, for representatives of the interests of the accused who wish to aid in the defense . . . these are questions pertaining to what may be called judicial culture. All these questions have exceptional significance in the strengthening of the authority of the Soviet Court." VysarsisEY, The Soviet Court and Soctalist Adamistration of Justice (1938) (in Russian) 52. "Judicial activity requires the deepest trust in the court. The judge must fight for this trust. . . . The basic task is to secure to the court the highest authority for its decision, in response to the requirements of the Great Stalin Constitution." Id. at 53.

86. Volfson, Faximy Law (1938) (in Russian) 26 et seg.

87. All-Umon Institute of JuRmical Science, 2 Crvil Law (1938) (in Russian) 417.

88. Collection of Laws of the Russian Soviet Socmlist Federated Repunlic (hereinafter cited as Colz. Laws, R.S.F.S.R.) (1917) No. 10, Art. 152; No. 11, Art. 160.

89. Code of Civil Status, Marriage, Family and Guardianship (hereinafter cited as 1918 Family Code), CoLL. Laws, R.S.F.S.R. (1918) No. 76-77, Art. 818. This was the first codified legal work of the new government.

90. "The complete break of the state power with canonical, religious, eeclesiastical views on marriage makes it possible to free the masses in this respect from the oppression of the priesthood." Goiknbarg, MardTal, Fanily and Guardisismip Law (1920) (in Russian) 12.

91. "It is to be understood that in publishing its codes the government of the proletariat engaged in establishing Socialism in Russia does not aim to make them of long duration. It does not desire to establish 'eternal codes.' . . . The proletarian government constructs its laws so that each day of their existence should make their continuance less necessary. . . . The proletarian power frankly acknowledges that its laws . . . are made to meet the neads of a period of transition, the duration of which it fervently desires to shorten. This period of transition is unavoidable; we may adopt measures to shorten its duration, but ve cannot leap across it." Goikhbarg, preface to an edition of the 1918 Family Code, cited in Ressusr SOVIET GOVERNMIENT BUREAU, op. cit. supra note 71, at 5-6. 
Code of $1926^{92}$ which relegated both marriage and divorce to the sphere of private agreement, with the control of the courts and of the state reduced to a minimum.

The reform in Soviet jurisprudence in 1936 and 1937 was preceded by new legislation on the family. The Law of May 31, $1935^{93}$ made parents criminally responsible for certain acts of their children. The Law of June 27, $1936,{ }^{94}$ prohibiting abortions, ${ }^{95}$ providing benefits for

92. Coll. Laws, R.S.F.S.R. (1926). The Code of Laws on Marrage, Famity and GuARDIANSEIP OF THE R.S.F.S.R. (Hsinwood Chao's trans. 1936). For a thorough exposition of the main provisions of the 1926 Code, carried down to 1939, see Hazard, Law and the Soviet Family, 1939 Wrs. L. REv. 224.

Under the 1924 U.S.S.R. Constitution, the right to formulate legislation concerning the family was not delegated to the central federal government but was retained by each republic. Constitutron of THE U.S.S.R. (1924) ART. 1 (o) and (p), n. 25: Article 3 of the Civil Code of the R.S.F.S.R. and corresponding articles of the civil codes of the other republics (except Azerbaidjan) provide that land relations, labor relations, and family relations be regulated by special codes. The R.S.F.S.R. being by far the largest republic, its Family Code is the most important and has been in fact the basis for the codes of the other republics. See Volfson, Fammy Law (1938) (in Russian) 23 et seq. Despite interesting variations in the codes of the different constituent republics and in legislation for autonomous republics within the constituent republics, particular laws cannot infringe the basic character of a Soviet Socialist Republic, which each constituent republic declares itself to be while remaining within the Union. Constitution of THE U.S.S.R. (1924) c. II, Covenant, and ConstretUTION of THE U.S.S.R. (1936) ART. 13. Moreover, important federal legislation was promulgated from time to time and introduced into all the different republican family codes. The 1936 Constitution requires that civil law be uniform throughout the Soviet Union, but no mention is made of family law in particular. In the draft civil codes which were prepared before the war, family law was included. See Mikolenko, System and Fundamental Principles of the Draft Civil Code of the U.S.S.R. (1939) 7 Soviex Justice (in Russian) 4,6. However, the debate has continued as to whether or not it should be. See Rabinovich, Revicw of Literature on Questions of Family Law (1941) 22 SoviET JUSTice (in Russian) 21. Meanwhile, the R.S.F.S.R. FAMrIU CODE may be taken as typical.

93. CoLL. LAws U.S.S.R. (1935) No. 32, Art. $252, \S 18$. "The police are authorized to fine the parents in an administrative procedure up to 200 rubles for the indecent conduct and street hooliganism of their children." By the Law of July 29, 1935 (CoLl. LAws U.S.* S.R. (1935) No. 2, Art. 344) parents were made civilly responsible for torts committed by their children.

94. Cold. LAwS U.S.S.R. (1936) I, No. 34, Art. 309.

95. The free performance of abortions in State hospitals, with criminal sanctions against their performance elsewhere, had been authorized by the Law of Nov. 18, 1920 (Colz. Laws R.S.F.S.R., No. 90, Art. 471). The purpose of this law, as expressed in its preamble, was "to protect the health of women and the interests of the race from ignorant and mercenary abortionists," who had "made for themselves a profession of this secret operation." Abortions were recognized as an evil, but "as long as the moral survivals of the past and the difficult economic conditions of the present still compel some women to decide on this operation," the method of repression was considered "absolutely unsuitable to its purpose."

The number of abortions increased in the twenties at an alarming rate. In Moscow, from 1921 to 1929 , births decreased from 30.6 per 1,000 inhabitants to 21.7, while abortions increased from 5.7 to 35.2. Statistical Review (1929) (in Russian) 128, cited by TuRiN, The U.S.S.R., AN Economic and Social SuRvey (1944) 18. 
mothers of large families, ${ }^{98}$ extending the protection of mother and child, ${ }^{97}$ and placing financial and procedural restrictions on divorce, ${ }^{53}$ reflected a new attitude; in a society in which law was now held to have positive and creative value, the family deserved all the legal support that could be given to it. This new attitude still had to make its way, however, against the chief provisions of the 1926 Family Code which was still in force.

By the Edict of July 8,1944 , as incorporated into the Family Code on April 16, 1945, ${ }^{99}$ discrepancies between the two phases of development of Soviet family law are largely resolved. So striking are the changes that unfriendly critics on the left have referred to them as a betrayal of Socialism, ${ }^{100}$ while from the right they have been viewed as part of a "Great Retreat." 101 Upon closer study, however, it is apparent that certain fundamental principles have survived from 1917 on. These include: (1) monogamy, (2) the lifelong character of marriage, (3) the equality of husband and wife, (4) the protection of illegitimate children, and (5) the protection of mother and child. What is new is

The Law of June 27, 1936 prohibited abortions except where called for by medical considerations. Abortions are now legal only "when the continuation of the pregnancy presents a danger of life or threatens grievous injury to the health of the pregnant woman or when the parents have a grievous disease which is transferable by heredity." Art. 1. The procedure for ascertaining the necessity of an abortion and a list of diseases which will warrant it is given in 8 Sovtet Justice (1937) (in Russian) 52.

96. Art. 10 establishes a State subsidy for mothers having six: children, at the birth of each succeeding child, of 2000 rubles annually for five years after the birth of the child, and for mothers having 10 children, at the birth of each succeeding child, of 5000 rubles for the first year and 3000 rubles annually during the succeeding four years. From 1936 to 1943, the Soviet Government expended approximately seven billion rubles on these allowances. Sverdlov, Legal Rights of the Soviet Fanily (1945) Sovier News 18.

97. Birth benefits were increased from 32 to 45 rubles, nursing benefits from 5 to 10 rubles per month (Arts. 5, 6); the length of vacation granted before and after childbirth was set at 56 days before and $\mathbf{5 6}$ days after for all women factory workers and ofice employees (Art. 8); criminal sanctions were established for refusal to hire women on account of presnancy and it was provided that pregnant women should be transferred to lighter work without reduction in wage (Art. 9). The network of maternity homes was to be extended (Arts. 11-13) and the number of crèches was to be doubled, and of nurseries tripled, by Jan. 1, 1939 (Arts. 14-21).

98. See p. 46 infra.

99. Edict of the Presidium of the Supreme Soviet of the U.S.S.R., July 8, 1944, 4 E:SBASSY OF THE U.S.S.R. Inforsration Bull., No. 84 (July 25, 1944). This edict, together with supplementary edicts of Nov. 10,1944 and March 14, 1945, was introduced into the Code of Laws on Marriage, Family and Guardianship by the Edict of April 16, 1945, published in 26 JourNal of THE Suprese SOVIET OF THE U.S.S.R. (May 11, 1945) 4.

100. See Koestler, The Yogr and the Condrsssar (1945) 168-170. "The procedure laid down for divorce amounts to an equivalent of the medieval pillory."

101. See Trmasheff, The Great Retreat (1946) 192 el seq. "After long years of destruction and experimentation, feverish efforts were made to restore the situation which existed at the outbreak of the Revolution or even earlier." Id. at 225. 
rather the protection by law which, in the interests of family security, these principles are now afforded.

Protection of Monogamy. Monogamy was from the beginning upheld in theory as the form of marriage best suited to a Socialist society, ${ }^{102}$ and in fact determined efforts were made to stamp out bigamy and polygamy in areas of Russia where those forms were a survival of old religious or tribal custom. ${ }^{103}$ Nevertheless, bigamy and polygamy are not punishable under the criminal law in those areas where they are not considered "socially dangerous." 104 Moreover, under the 1926 Family Code as interpreted by the courts, a bigamous marriage was valid. ${ }^{105}$

102. In spite of extremist views such as those of Kollontar, op. cil. supra note 63, the principle of monogamy was deeply rooted in Marxist-Leninist philosophy. See p. 35 supra.

103. Under Imperial Russian Law the marriage impediment of an already existing marriage was not applicable to persons whose religious doctrines did not prohibit polygamy. See note 17 supra. Under Soviet law, bigamy and polygamy are listed as crimes under those sections of the criminal codes of the various republics which deal with survivals of kinship life. This applies mainly to Mohammedans, who comprise more than ten per cent of the total population of the U.S.S.R., living for the most part in Turkestan, Central Asia, and the eastern part of the Caucasus. In the R.S.F.S.R., bigamy and polygamy are punishable, where they are survivals of an earlier form of family life, by correctional labor up to one year or a fine up to 1000 rubles. Crumrnal Code, R.S.F.S.R., Art. 199.

104. Bigamy was a sociological rather than a legal concept. "We do not recognize bigamy as a socially dangerous act except in those cases when bigamy crops up from the soil of economic exploitation. In autonomous national republics we not only forbid bigamy and polygamy in general, but we prosecute it in criminal law. . . . Why do we speak this way? Because we look on bigamy in the national republics as a relic of tribal society, which has as its basis the exploitation of woman's toil." BRANDENBURGSWII, COURSE IN FAMILY and Marriage Law (1928) (in Russian) 56. See Hazard, Law and The Soviet Family [1939] WIS. L. REv. 224, 242. Similarly, though marriage with a minor is punishable by deprivation of liberty up to two years where it occurs as a survival of tribal life (Cunnenal Conz, R.S.F.S.R., Art. 198), it was officially stated in 1929 that "entering into a factual marriage with a minor (under 18 years of age) who has reached sexual maturity is not a socially dangerous act, and it will not be examined in court proceedings." Interpretation of the Flentum of the Supreme Court of the R.S.F.S.R., April 15, 1929, 2 Judicial Practice (1929) (in Russian) 2. This does not apply to those localities (autonomous republics and regions) in which Art. 198 of the CRrminal CoDe is effective. Interpretation of the Plenum of the Stbpreme Court of the R.S.F.S.R., June 6, 1930, 94 Judicial Practice (1930). Incest is not included as a crime for similar reasons. "For Soviet criminal legislation, in the question of the recognition or non-recognition of incest as a crime, only considerations of the development of a healthy generation can have significance. The original draft Criminat CoDE of the R.S.F.S.R. in 1922 contained a special article recognizing incest as a crime. But in the consideration of the draft at the session of the All-Russian Central Executive Committeo this article was excluded. Evidently the legislator considered it unnecessary to recogniza incest as a crime, because it is not socially dangerous, since the existing negative attitude toward this kind of phenomenon serves as an adequate restraining factor in its development. In practice, incest occurs only as a rare exception, and is not a threat of degeneracy. The criminal codes of the Georgian and Azerbaidjan Soviet Socialist Republics, however, include incest as a crime." Criminal Law, Special Part (1939). All-Union INSTITUTE of JuRudical SCIENCE (in Russian) 229.

105. "A double marriage is indeed inadmissible, but in and of itself as an exceptional 
This anomalous situation arose from the doctrine that marriage is a de facto relationship springing from mutual consent and cohabitation. ${ }^{\text {If }}$ Civil registration of marriage, which had been introduced in 1917 as a weapon against the influence of the clergy, ${ }^{107}$ was declared optional in the 1926 Code; registration was simply evidence of, and did not itself constitute, marriage. ${ }^{103}$ Thus registration of a bigamous marriage, though illegal, did not void the marriage. ${ }^{103}$ The impediments to the registration of a marriage ${ }^{110}$ were, properly spealing, registration impediments rather than marriage impediments.

occurrence has no consequences. Therefore there is no basis for placing on the second wife of the deceased legal consequences disadvantageous to her which arose from the fault of the testator." Case reported in 19 Judicrat Practice (1927) (in Russian) 11, in which both wives were permitted to inherit as wives. It was stated categorically as an order of the Supreme Court of the R.S.F.S.R. that where there is a contest over the property of the deceased spouse between two persons who can prove all that is needed to establish a de foelo marriage existing at the time of the spouse's death, claims of both are recognized and the property is divided. Order of College of Civil Cassation of the Supreme Court of the R.S.F.S.R. 16 JUDICIAL PRACTICE (1929) (in Russian), abstracted in the 1936 edition of the FAImLY CODE, R.S.R.S.R., as an annotation to Art. 11.

106. "The following circumstances serve for the courts as proofs of marital cohabitation in cases'where marriage is not registered: the fact of joint cohabitation, in case of such cohabitation a common household, statements made to third persons in personal correspondence and in other documents proving the existence of marital relations, and alco, according to circumstances, mutual financial support, joint education of children, etc." FArril CODE, R.S.F.S.R., Art. 12 prior to amendment of April 16, 1945. "The listed evidences are to be viewed only as exemplary, typical." Volfsox, Fusmy Latr (1938) (in Russian) 51 .

107. Church weddings were not prohibited under the 1918 FusmY CODE, but marriage took place only from the moment of civil registration. It was felt that without the requirement of civil registration, people would simply continue to be married in a religious ceremony. This was stated explicitly. Where a marriage was not registered and the reasen for failure to register was not religious, the marriage was recognized. Goinnbarg, Miarumal, Fanil y and Guardianship Law of tae Soviet Republic (1920) (in Russian) 37.

108. Registration was chiefly valuable as evidence in establishing paternity, the rights of succession, right to support and maintenance, etc., and as the basis for statistics.

If a man registered a marriage in Mioscow with $\mathrm{X}$, and then moved to another place and entered into a factual marriage with $Y$, "it is clear that according to the whole spirit of Soviet Law, all juridical consequences of the marriage arise not with $\mathrm{X}$ but with $\mathrm{Y}$." Volfson, Fasmy LAw (1938) (in Russian) 51. See Circular of the People's Commissariat of Justice, Oct. 26, 1934: "In the decision of the question of the existence of a marriage according to Soviet legislation, it is necessary to proceed from the position that factual marriage is the decisive fact."

109. The 1918 FAnImY CODE declared a marriage void where it was registered in violztion of the marriage impediments of insanity, incest, or polygamy (Arts. 69, 78-81). The 1926 F A Irr Y CODE made no provision for nullity of a marriage. A false concealment of a still existing marriage at registration of a second marriage is punishable under Art. 88 of the CRnIINAL CODE not for bigamy but only for communicating wrong information to the registry organs. Annotation to FAMILY CODE, R.S.F.S.R., Art. 4, reported in the 1936 edition. See note 108 supra.

110. To register a marriage lawfully under the Farmy CODE, R.S.F.S.R., both parties must consent, both must be 18 years of age, sane, unrelated in the direct line of descent or. 
With the reaffirmation of the importance of the family in 1935 and 1936, the courts and law-writers became more emphatic in their disapproval of bigamy. It was stated that "there can be only one marriage at a time," 111 and that when disputes arise over inheritance and two people claim to be wives, "the court must decide which is the actual marriage." 112 Also it was held that a marriage registered illegally, with a prior registered marriage undissolved, does not create any juridical consequences for the parties, since "the registration of the second marriage was illegal and subject to annulment." 113 Meanwhile the courts became stricter in their requirements for proof of de facto marriages. ${ }^{114}$ This development has culminated in the new legislative provision that "only a registered marriage shall create the rights and duties of spouses prescribed in the present Code." 115

The new requirement of registration is more than an administrative matter. To emphasize the constitutive nature of the registration, it is provided that there shall be a "solemn procedure" with "suitable premises properly furnished," and the issuance of "certificates duly drawn up." 116 So far from being a weapon for the secularization of marriage, the present system seems to look to the return of ceremony. ${ }^{117}$

But an examination of Communist ideals in the first years of the Revolution discloses that the purpose of the movement to secularize marriage and free it from all controls was not to weaken monogamy, ${ }^{118}$

as brothers and sisters. Arts. 4-6. Regarding sickness other than insanity or feeblemindedness, the law demands only that the spouses mutually inform each other of their state of health, especially in regard to venereal, mental and tubercular diseases. They must also state how many marriages each of them has previously contracted, and how many children each of them has. Art. 132.

111. Volfson, Family LaW (1938) (in Russian) 81, criticizing the 1934 ruling of the R.S.F.S.R. Supreme Court cited supra note 23.

112. All-Union Institute of Juridical Science (1938) 2 CiviL Law (in Russian) 429.

113. Tsvetkova v. Beliaeva-Lazareva, reported in 20-1 Soviet Justice (1938) (in Russian) 93.

114. See 1 Soviet Justice (1940) (in Russian) 41.

115. FaMILY CODE, R.S.F.S.R., Art. 1 as amended April 16, 1945.

116. Edict of July 8, 1944, cited supra note 99 , Art. 30 .

117. Even before the new legislation was promulgated, the formalities of the marriage ceremony had come to be stressed. See ERDE, MarRIAGE aND THE FAMILY IN THE U.S.S.R. (Soviet Booklets, No. 2, 1943) 3-4. It was reported recently that "wedding rings-something of a rarity in the Soviet Union since the 1917 revolution-are back on jewelry counters and women are rushing to buy them ... (since) the custom of wearing them has been revived." N. Y. Herald-Tribune, Nov. 17, 1945, p. 4, col. 4.

118. Sexual promiscuity was condemned by the leaders of the Revolution. Lenin wrote: "The changing attitude of youth to the question of sex relations is referred, of course, "in principle' to theory. Many call their position 'revolutionary' and 'communistic'. . . . All this has nothing in common with free love as we communists understand it. You know, of course, the significant theory that in a communist society to fulfill sexual desires and lovo drives is as simple and meaningless as to drink down a glass of water. From this 'glass of .water' theory our youth has gone mad, gone completely mad. It has become the evil fate 
but rather to liberate monogamous marriage from external and traditional restraints which were considered to be hypocritical as well as injurious to the interests of the marriage. This purpose was frustrated, however, by the frivolous attitude that developed toward civil registration and toward marriage and divorce generally. ${ }^{110}$ Thus, in requiring registration as the constitutive element of marriage, and thereby making bigamous marriages void, Soviet jurists have invoked the protection of law ${ }^{120}$ for an ideal which, in the absence of law, was in danger of being lost.

Protection of Marriage. Despite theories of the ultimate "withering away" of the family and the achievement of "formless" marriage, Soviet courts early held that "the intent at the time of marriage must be to form a relationship for life." ${ }^{122}$ It was rather to guarantee than to undermine this lifelong relationship that freedom of divorce was instituted. ${ }^{123}$ And this was done with characteristic thoroughness.

Under the Family Code of 1918, divorce could be obtained without a hearing by the application of both parties to the Civil Registry Bureau ${ }^{124}$ or by the application of one of the parties to the People's

of many young men and girls. Its devotees assert that this is Marxist theory. Thanls you for such Marxism." Tsetern, ON LenIN, Recollections aNd MeEtras (1925) (in Russian) 115-6.

See Volfson, FanmI Law (1938) (in Russian) 18 el seq., on the distinction between the "formal" monogamy of bourgeois society and "real" monogamy under Socialism.

119. "It was believed that many marriages were contracted for convenience-to secure a room in the crowded city, for example-and then followed by divorce." Fousos, TaE Faxily aNd Dexocratic SocIETy (1943) 198, in connection with the high divorce rate in Moscow in 1934. The Law of June 27, 1936, p. 40 supra, states in its preamble that its aim is to further the struggle "against the frivolous attitude toward the family and family obligations."

120. "The principle distinction (of Soviet law) in this respect from bourgeois law, which also prescribes monogamy, consists in the fact that Soviet law is not limited to the formal introduction of this principle, but to the maximum degree guarantees its realization. In consequence of this [Soviet] family law is a powerful means of actively inculcating the monogamous marriage into life, while in bourgeois countries the rule of single marriage is a hypocritical cloak to factual polygamy among the ruling clusses." VOLFSO:, FAuInY L.AW (1938) (in Russian) 7.

121. See p. 36 supra.

122. "If any shorter term is in mind, it may be cause to subject the delinquent to criminal prosecution for rape brought about by the use of fraud and delusion." Interpretalion of the Plenum of the Suprente Court of the R.S.F.S.R., Feb. 6, 1928, 4 Judichul Pricice (1928) (in Russian) 3.

123. "Reactionaries are against freedom of divorce, and call for a 'careful handling" of it, shouting that it signifies 'the disintegration of the family.' But democracy assumes that the reactionaries are being hypocritical . . . that in fact freedom of divorce signifies not the 'disintegration' of family ties, but on the contrary the strengthening of them on the only' possible firm democratic foundations in a civilized society." 17 LENr, Works (in Russian) 448.

124. Literally, "Registry of Acts of Civil Status," abbreviated in Russian as "ZAGS." These bureaus were set up as quickly as possible all over the Soviet Union as bureaus of vital statistics. Previously, such functions had been performed by the clengy. 
Court. ${ }^{125}$ With the 1926 Code, even this simple procedure became unnecessary: a de facto divorce was accorded the same legal recognition as a registered divorce. ${ }^{126}$

The Law of June 27, 1936 attempted to deal with abuses arising from the ease with which marriage and divorce could be registered by requiring the appearance of both parties at the Civil Registry Bureau and the notation of the divorce in their identification papers, and by instituting progressively increasing fees for registered divorces. ${ }^{127}$ These changes in the law on registered divorce were inadequate, however, to cope with the flippant attitude toward de facto marriage and divorce. ${ }^{128}$

The new family legislation of 1944 and 1945 restores divorce to the jurisdiction of the courts ${ }^{129}$ and authorizes the following procedure: A petition for the dissolution of a marriage is submitted to the People's Court, giving reasons for the divorce; when filing the petition, the sum of 100 rubles is paid. ${ }^{130}$ The court summons the party against whom the petition has been filed, to acquaint him or her with the contents of the petition, to ascertain the motives for the divorce, as well as to establish what witnesses are to be summoned during the court proceedings. ${ }^{131}$

125. The People's Courts are at the bottom of the Soviet hierarchy of courts. They havo jurisdiction over crimes generally, though certain important criminal cases are reserved by statute for the higher courts, and over civil disputes between private parties, between collective farms, and between holders of a concession or a foreign firm and governmental agencies involving up to 10,000 rubles. A People's Court consists of a People's Judge, formerly elected for one year, now elected for three years, and two People's Assessors, who correspond to our jurors in the method of their selection but who sit as judges on equal terms with the People's Judge. People's Judges are nominated by social, party and professional organizations and are elected by the people of the county (raion) over which the court has jurisdiction. Vyshinsky (ed.) Soviet Public Law (1938) (in Russian) 453-60.

126. A de facto divorce could not be registered, but could be confirmed by a declaratory judgment of the court. FAMmy CoDE, R.S.F.S.R., Arts. 19, 20.

127. Law of June 27, 1936. Coll. Laws, U.S.S.R. (1936) I, No. 34, Art. 309, Art. 27. However, substituted appearance was permitted. Col.. LAws, R.S.F.S.R. (1937) No, 6, Art. 40, introduced into the FAMruY CodE, R.S.F.S.R., as Art. 140.

128. In 1934, in Moscow, there were 37 divorces for every 100 marriages, and in the first half of 1935 the proportion increased to 38.3 per 100. Izvestia, July 7, 1935 (in Russian). See note 119 supra. These statistics apply to registered marriages and divorces.

It was felt that a discrepancy existed between the spirit of the Law of June 27, 1936 and the institution of factual marriage and divorce. The conclusion was drawn that the provisions of the Family Code equalizing factual and registered marriage and divorce had lost their force. Goikhbarg, Factual Marriage in Soviet Law (1941) 1 Soviet State ANd LAW (in Russian) 70.

129. "During the lifetime of the spouses the marriage may be discontinued only by means of a divorce by the court upon petition of one or both spouses. Divorce shall be conducted publicly. At the request of the spouses the divorce case may in necessary instances, at the discretion of the court, be heard in closed judicial session." FAMILY CODE, R.S.F.S.R., Art. 18 as amended.

130. FAMII, CODE, R.S.F.S.R., Art. 19 (a) as amended.

131. FaAmL CODE, R.S.F.S.R., Art. 19 (b) as amended. 
Announcement of the filing of a petition for divorce is published in the local newspaper at the expense of the party filing the petition. ${ }^{132}$ The People's Court is obliged to take steps to reconcile the parties. If no reconciliation is effected, the petitioner has the right to file a petition for divorce with a higher court; ${ }^{133}$ the higher court, ${ }^{134}$ if it deems it necessary ${ }^{135}$ to grant the divorce, determines the custody and support of children, establishes a procedure for the division of property, restores to the parties their original surnames if they so desire, and fixes the sum to be paid by one or both spouses on issuance of the certificate of divorce. ${ }^{136}$ On the basis of the court's decision, the Civil Registry Bureau draws up the certificate of divorce, makes a corresponding entry in the passports of the parties, and collects from one or both a sum ranging from 500 to 2000 rubles as directed by the court. ${ }^{137}$

These provisions make divorce a serious matter in the Soviet

132. Farril X CODE, R.S.F.S.R., Art. 19 (c) as amended.

133. FAMIII CODE, R.S.F.S.R., Art. 20 as amended. This system of dividing divorce procedure between two courts, the first of which has the sole function of attempting to reconcile the parties, is familiar to European law generally and was part of the canon law divorce procedure of pre-revolutionary Russia. Compare also the current divorce procedure of the Magistrate's Court of New York City.

134. "The regional, provincial, district or city courts and the Supreme Court of the autonomous republics shall be competent to render a decision of dissolution of marriage." FAMILY CODE, R.S.F.S.R., Art. 21 as amended. The courts named are on the second level of the Soviet hierarchy of courts, their different names arising from the different geosraphical areas over which they have jurisdiction. Their judges are elected for a period of five years by the soviets (councils) of their respective areas. They function as courts of original jurisdiction in more important criminal cases and in all civil cases beyond the jurisdiction of the People's Courts, consisting in such cases of a judge and two assessors. See note 125 supre. With three judges sitting, they function as appellate courts in cases decided by the People's Courts, and their decisions in that capacity are final. But see note $161 \mathrm{infra}$. It is not stated in the new family legislation whether in divorce cases the higher courts shall sit as courts of original jurisdiction or as courts of appeal. If they sit as courts of original jurisdiction, an appeal will lie to the Supreme Court of the constituent republic, whose judges are elected by the Supreme Soviet of the constituent republic for a term of five years. The decisions of these courts are final, though the case may be brought "by way of supervision" before the Supreme Court of the U.S.S.R. on protest of the President of the Supreme Court of the U.S.S.R. or on protest of the Procuracy. See note 161 infra. The members of the Supreme Court of the U.S.S.R. are chosen by the Supreme Soviet of the U.S.S.R. for a term of five years. This is the only federal court. VysurNsky, op. cit. supra note 125, at 448 etseq.

135. No grounds for divorce are stated. The phrase "in the event that it is deemed necessary" (v sluchae priznaniia neobhlodimosti) is used. Fassin CODE, R.S.F.S.R., Art. 22 as amended. This is the customary language for giving the court full discretion. In the translation of the corresponding article (Art. 26) of the Edict of July 8, 1944, cited stsfra note 99 , it is stated that the higher courts "which decide that the marriage should be annulled, must" etc. This is a misleading translation, in view of the fact that hitherto there -has been no concept of grounds for divorce in Soviet Law and it is therefore possible to construe such a translation as making it obligatory upon the higher court to grant the petition.

136. FAurity CODE, R.S.F.S.R., Art. 22 as amended.

137. Farmy Code, R.S.F.S.R., Art. 138 as amended. 
Union. ${ }^{138}$ They make divorce expensive. ${ }^{139}$ They restore jurisdiction over divorce to the regular judicial bodies. Moreover, until explicit grounds for divorce are developed either by legislation or by judicial decision, the higher court has full discretion to grant or refuse a petition.

As in the case of monogamy, so in the case of marriage as a lifelong institution, the Soviet Union has turned to law as a means of preserving original ideals which were in danger of being lost through the abuse of freedom. At the same time, it is explained that with the achievement of Socialism, ${ }^{140}$ social and economic conditions are such as to make divorce an exceptional and irregular occurrence, to be discouraged as contrary to the welfare of society. ${ }^{141}$

Protection of the Equality of the Spouses. It was the aim of Soviet legislation from the beginning to deliver the woman from her traditional legal disabilities and to emancipate her from all subservience to her husband. ${ }^{142}$ Women went into industry, ${ }^{143}$ the learned professions, ${ }^{144}$

138. "Russian divorces have dropped by two-thirds in the 16 months since the announcement of edicts designed to strengthen family ties, Moscow Legal Comptroller Vladimir Sukhodrev said today. The principle reason for the decreases, he said, was that the divorce process has been made public and turned over to the courts." N. Y. Herald-Tribune, Oct. 25, 1945, p. 4, col. 4. Other than such announcements as these, no statistics are available in this country. Also no mention of the actual working of the new law has been found in any of the scattered Russian legal publications that have reached this country in the last two years.

139. The fees have been termed prohibitive for the average wage-earner. See LASERSON, RUSSIA AND THE WESTERN WORLD (1945) 29. This does not take into account, however, increased wages during the war. Thus, whereas in 1935 the average monthly wage for all wage and salary earners was 190 rubles, with engineers and technicians receiving 436 rubles, Socialist Construction in the U.S.S.R. (1936) Statistical ABSTRACT 368, 385, cited by DobB, Soviet Planning and Labor in PeAce AND WAR (1943) 91, recent observers report that the average monthly wage for a city worker during the war was approximately 900 rubles. See LAUterbach, These are the Russians (1945) 187, 206, 214, 221.

140. "Our Soviet society has reached a point where it has already achieved, fundamentally, Socialism, has created the Socialist structure, i.e., has achieved that which among Marxists is called the first and lowest phase of Communism." Stalin, Report on trie Draft Constitution of THE U.S.S.R. (1936), cited in All-Union Institule of Juridical Science (1938) 1 Crvil Law (in Russian) 8.

141. Sverdlov, Soviet Laws on Family and Marriage, Moscow NEws, March 28, 1945.

142. See p. 29 el seq. supra.

143. In 1940, there were 11 million women workers and employees, constituting over 37 per cent of all wage-earners in the Soviet Union, and 19 million women workers on col. lective farms. Of the women in industry, there were 60,000 lathe-hands and 40,000 fitters in the metal-working industry, 24,000 milling-machine operators, 14,000 tool-and-dic makers, and 170,000 engineers and technicians. Izvestia, March 8, 1941 (in Russian). By 1946 the number of women engineers and technicians had risen to more than 250,000. Pravda, March 8, 1946 (in Russian). In 1939 over 4000 women were driving railroad engines, and nearly $\mathbf{5 0 0 0}$ were taking courses in engine-driving. SEREBRENNIKov, WOMAN IN THE Soviet Union (1943) 13. See Grunfeld, Women's Work in Russia's Planned EconoMY (1942). In pre-revolutionary Russian industry altogether there were only 200 to 300 skilled women workers, according to Serebrennikov. Id. at 27.

144. The number of women possessing a secondary education was estimated in 1939 at 
politics ${ }^{145}$ and the army, ${ }^{146}$ in large numbers, and often in positions of leadership. Under the Constitution, ${ }^{147}$ they received the right to an equal wage for equal work. Emancipation of women became a national program, and attempts to obstruct it were punished under the Criminal Code as counter-revolutionary crimes. ${ }^{145}$ Similarly, the position of the woman in the family was strengthened. Parents, relatives or guardians who prevented a woman from entering into marriage, or who persecuted her after she had married against their will, were held punishable under the criminal law. ${ }^{149}$ The wife was given a legal remedy against rape by her husband. ${ }^{150}$ She could recover damages under the Civil Code for personal injury by him. ${ }^{151}$ And the Family Code gave her the freedom to keep her own name, to choose her occupation or profession, to have an equal share in the conduct of a common household or to live apart if she prefers. ${ }^{152}$ Community of property acquired during mar-

$6,000,000$. Over 1,500,000 of these were in spheres of pedagogy, science, art and journalism. SEREBRENNIKov, op. cit. supra note 143 , at 25 . There were 72,600 woman doctors, comprising 60 per cent of the total number, while in Tsarist Russia there were only 20,000 doctors all told, and of these 1900 were women: $I d$. at 26. In 1946 there are 1,050,000 women working in public health institutions, of whom 100,000 are doctors, and 33,000 women are conducting scientific work in research institutes. Pravda, March 8, 1946 (in Russian).

145. In the 1939 General Election, 457,000 women were elected as deputies to regional, district, urban and rural soviets (councils); 1480 women were elected to the Supreme Soviets of the various constituent and autonomous republics, and 227 were elected to the Supreme Soviet of the U.S.S.R. SEREBRENnIKov, op. cit. supra note 143, at 7. The newly elected Supreme Soviet of the U.S.S.R. includes 277 women deputies. 6 ExBassY of THE U.S.S.R. Inforiration Bull., No. 24 (March 12, 1946) 203. The total number of deputies is 1,339. Id., No. 26 (March 16, 1946) 217.

146. "Some 120,000 women in the services have been awarded combat decorations, and 62 have won the title of Hero of the Soviet Union." 6 Esrb.issy of TuE U.S.S.R. IsForasation Bull., No. 24 (March 12, 1946). See Sibiriak, Soviet Wousen in the War ag.MNSt HITLERISM (1942).

147. Constitution of the U.S.S.R., ART. 122.

148. Order No. 27, Plenum of the Supresre Court of the U.S.S.R., 1929 (in Russian).

149. 21 Judiclal Practice (1938) (in Russian) 1.

150. Crimmal CODE, R.S.F.S.R., Art. 153. Interpreting the corresponding article of the 1922 Criminal Code, the Plenum of the Supreme Court stated, Mlay 18, 1935, that "marriage in Soviet Law is the free cohabitation of a man and a woman, and is not a right of the husband, founded on contract, to sexual relations and a duty of the voman to present her body for the satisfaction of the sexual desires of the husband." Criumsial Liw, Specins Part (1939). All-Union INstitute of Juridical Science (in Russian) 213. Also, a person who has entered into a registered marriage for the purpose of using a woman in sexual relations and with the intention of divorce after the marriage is punishable under Art. 153. See note 122 supra.

151. Crvil CODE, R.S.F.S.R., Art. 403. "Damages adjudged to one spouse due to some tortious act of the other spouse are independent of alimony." (Alimony in Russian Law refers to support, independent of any question of divorce.)

152. FAMILY CODE, R.S.F.S.R., Arts. 7, 9. 
riage was established, ${ }^{153}$ and the wife received a share in her husband's estate at his death. ${ }^{154}$

With the shift of emphasis from woman as wage-earner to woman as wife and mother, the principle of her equality with her husband has not been abandoned. None of the rights previously established has been revoked. On the contrary, in her property relations with her husband, the wife has been held to have joint control of property acquired during marriage to the extent that the husband cannot alienate it without her consent. ${ }^{155}$ Moreover, the economic position of the mother has been reinforced by the payment of money grants to mothers of large families, ${ }^{156}$ with the provision that these grants are the personal property of the mother and not part of the community property of the spouses. ${ }^{167}$

Protection of Children born out of Wedlock. Early Soviet law reflected a conception of the family as based primarily on descent rather than on

153. FAsily CODE, R.S.F.S.R., Art. 10. Under the 1918 FAMILY Code, Art. 105, each spouse owned separately what was acquired by him or her. This was modified by the courts, which began to give the wife a share in the husband's property on the basis of her domestic work. "The formula of 1918 proceeded from the principle of formal equality, which in fact was bound to lead to real economic inequality if (judicial) practice had not supplemented and corrected it." Reikhel, General Property Relationships of the Spouses in Soviet Law (1940) 8-9 Soviet State and Law (in Russian) 109, 111.

154. Inheritance was declared abolished on April 27, 1918 [CoLt. LAws, R.S.F.S.R. (1918) No. 34, Art. 456], but where the estate was less than 10,000 rubles close relatives of the decedent were permitted to take. The limitation of 10,000 rubles was later declared not to refer to enterprises not hiring labor. Concessions were also made for peasant farmsteads. The 1922 Civil Code reestablished inheritance, but limited the estate to 10,000 gold rubles, exclusive of all debts of the decedent, as well as of furniture and household objects and of State contracts with private persons (e.g., concessionaires, tenants, etc.). In 1926, the 10,000 rubles limitation was removed altogether and replaced by a heavy progressive tax up to 90 per cent. The 1922 Civil Code also established a closed circle of persons capable of inheriting either by will or at law. CrvIL CODE, R.S.F.S.R., Art. 418 prior to amendment of 1945. This circle was limited to the direct descending relatives, to adopted children with their descendants, and to the surviving spouses of the decedent, as well as to persons unable to earn and destitute who had been entirely supported by the decedent for not less than one year before his death. Under the law of intestate succession, all took equally per capita. Id., Art. 420. Any member of the class permitted to take by way of intestacy could be the legatee of any amount up to the entire estate, $i d$., Art. 422 , provided that minor children could not be deprived of more than one-fourth of their share. Id. n. 2. See Serebrovskii, History of the Development of Soviet Inheritance Law (1945) ACADEMY OF SCIENCE OF THE U.S.S.R., QUESTIONS of Soviet Crvil Law (in Russian) 156. For recent changes in the law of succession, see note 178 infra.

155. Reikhel, op. cit. supra note 153,113-4 cites an instruction of the People's Commissariat of Justice of the R.S.F.S.R., Nov. 17, 1939, which declares that for alienation by a spouse of a house acquired after marriage, the consent of the other spouse is required, unless such house is acquired by inheritance. Reikhel interprets the provisions of the Civil Code on the share of each spouse in the common property to apply only after divorce. But sce Rabinovich, Review of Literature on Questions of Family Law, 23 Soviet JUstrce (1941) (in Russian) 24, 26-7.

156. See note 186 infra.

157. Edict of May 22, 1937, ColL. Laws, U.S.S.R., 1937, No. 35, Art. 145. 
marriage. ${ }^{15 s}$ An attempt was made to separate the question of marriage from the question of the family. This found expression in the doctrine of full equality of extra-marital with marital children. The unmarried mother could demand support during and immediately after pregnancy from the putative father of the child; the father had, moreover, the full paternal obligation of maintenance, support and supervision of his natural child, who in turn had full rights of inheritance from his father. ${ }^{159}$

The technical problems involved in this solution were very great. ${ }^{163}$ The Procuracy ${ }^{161}$ was troubled with the problem of tracking down missing fathers. The courts were troubled with the problem of finding methods to establish paternity. Even after the establishment of paternity, enforcing payments for support proved difficult. Moreover, with the recognition of the importance of the home, it was felt that the marriage of the parents was essential to the welfare of the children.

The Edict of July 8, 1944 eliminated the paternity suit from Soviet jurisprudence. ${ }^{162}$ In so doing, it emphasized again the importance of

158. "Soviet legislation, having broken with the foundations, having destroyed the foundations of the bourgeois order, sharply separated the marital union, as a voluntary agreement between two persons of different sex, from kinship, as the union based on the natural fact of descent, or, as it may be expressed, common blood. It retained only blood relationship. ..." The fact that marriage, the family and guardianship, three separate things, are contained in one Code "does not in the least testify to the retaining of their inner unity, but is rather a historical survival." GorkgBarg, MLariral, Fauml and GuardolasSHIP LAW OF THE SOVIET REPUBLIC (1920) (in Russian) 5.

159. FAxiry CODE, R.S.F.S.R., Arts. 28, 29, 30 prior to amendments of April 16, 1945. The exceptio plarium was no defense to a paternity suit. Under the 1918 Fusmy CODE, Art. 144, where any of several men could have been the father, all were jointly and severally responsible. Practice showed that this system did not work to the advantage of the child, since none of the men felt wholly responsible. Brandensurgszir, Course IN Fasm ard Marriage Law (1928) (in Russian) 109. The 1926 Code, Art. 32, required the court to decide which of any alleged fathers was the actual one.

160. The Soviet law journals have treated the problems arising from paternity suits often and at length. See, for example, Kopelanskaia, Some Legal Questions of Disputed Paterrity (1940) 4 Socialist Legality (in Russian) 80.

161. The Procuracy supervises the observance of laws by the courts and by administrative institutions, and also exercises the functions of State prosecution in criminal cases. The Procurator of the U.S.S.R. is appointed by the Supreme Soviet for a term of seven years, and he appoints procurators for the constituent republics, territories, and autonomous republics, who in turn appoint district, regional and city procurators. The Procurator may authorize the records of any case to be sent to the Supreme Court from any court at any" stage of the proceedings for a review "by way of supervision," i.e., without motion by the parties.

162. Faniry CoDe, R.S.F.S.R., Art. 29 as amended. The child receives the surname of the mother with whatever patronymic the mother indicates. Id., Art. 27 as amended. The significance of this requirement is modified, however, by the fact that under Art. 7, the spouses, on marriage, may take as a surname either that of the husband or wife or may retain their ante-nuptial surnames. 
the marriage relationship to family life. At the same time no social stigma is attached to the extra-marital child. On the contrary, the unmarried mother receives from the state an allowance for the support of her child until it reaches the age of 12 , and if she has three or more children, she is entitled to the regular allowances for mothers of large families in addition to her special allowances as an unmarried mother. ${ }^{103}$ If she wishes to place her child in an institution for children, the institution is obliged to accept the child, who will be maintained and brought up at the full expense of the State. However, the mother has a right to reclaim the child from the institution if she so desires. ${ }^{164}$

Thus while the child born out of wedlock is no longer treated as his father's child, the state has stepped in to assume a large share of the paternal obligation. The principle that the extra-marital child deserves equal protection with the child whose parents are married, is modified only in so far as the extra-marital child is now afforded as much protection, though of a different kind.

Protection of Mother and Child. Early Soviet legislation was predicated on the hypothesis that with the achievement of the final stage of Communism, the family would no longer exist as an individual unit but would be collectivized, with the children brought up in special institutions. ${ }^{165}$ To this end, and for political reasons, ${ }^{166}$ it was sought to weaken the authority of the parents over the children, and to transfer that authority to the state. The protection of mother and child, which is one of the primary objects of Soviet family law, ${ }^{167}$ was to be achieved by liberating them from the material and moral domination of the father and by the establishment of crêches and kindergartens ${ }^{168}$ to care

163. Edict of July 8,1944 , cited supra note 99 , Art. 3. The mother receives 100 rubles a month for one child, 150 rubles for two children, and 200 rubles for three or more.

164. Id., Art. 4. While the child is in the institution no allowance is paid to the mother.

165. Adoption was abolished by the 1918 Code for that reason, and all children who were without parental tutelage were to be placed in State institutions of guardianship. "Our guardianship . . . must show parents that the social care of children gives far better results than the private, individual, inexpert and irrational care of individual parents who are 'loving' but, in the matter of bringing up children, ignorant." GolkHbarG, op. cil. supra note 158, 5. See Dombrovskii, Adoption and Guardianship in Kurski, Collectron of Articles and Materials on Marital and Family Law (in Russian) 71. Because of the great demand for adoption, however, it was permitted in effect by the Land Code of 1922, Art. 66, and was finally authorized by the Law of March 1, 1926, ColL. LAws, R.S.F.S.R. (1926) No. 13, Art. 101, which was included in the 1926 Family Code as Chapter III.

166. With their pre-revolutionary upbringing, the parents were felt to be a reactionary ideological influence. See Hazard, The Child under Soviet Law (1938) 5 U. of Cr1. L. REv. $424,429$.

167. The Decrees on Marriage and Divorce of 1917, cited supra note 88, declared the protection of mothers and children to be "the direct duty of the State." See Constirution OF THE U.S.S.R. 1936, Art. 122, which speaks of "State protection of the interests of mother and child."

168. In' 1940 more than $7,000,000$ children under seven years of age were cared for in nurseries and other pre-school institutions. SEREBRENNIKov, WoMAN IN THE SOvirt UNION (1943) 12. 
for the children and so to free the mother.from the slavery of the kitchèn. ${ }^{169}$

The alarming spread of juvenile delinquency ${ }^{170}$ led to the recognition, in the 'thirties, that the personal care of children by the parents is superior to mass supervision in public institutions. ${ }^{171}$ Further, it was emphasized ${ }^{172}$ that not only do children need parents but also parents need children, and that the bearing and bringing up of children is important not only for the happiness of the family but also for the welfare of the state. ${ }^{173}$ Law played a leading part in this movement to strengthen family ties, both through court decisions ${ }^{174}$ and through legislative enactments, of which the laws of May 31, 1935 and June 27, $1936^{175}$ were only the most prominent of a series. Housing law encouraged the private construction of single family dwellings. ${ }^{170}$ Life

169. "No nation can be free when half the population is enslaved in the kitchen." Lenin, quoted by Folsom, op. cit. supra note 119.

170. The extent of the evil may be judged by the character of the remedy which was applied. The Law of April 7, 1935 "On Measures to Combat Criminality among Minors," Coll. LAws, U.S.S.R. (1935) No. 19, Art. 155, requires that youths from 12 years of age who commit larceny, rape, bodily injury, mutilation, murder, or attempted murder be tried in the regular courts and punished under the regular provisions of the criminal codes. The former juvenile courts were abolished. In practice the strictness of some of these provisions was modified. Thus, conditional sentences are given in most cases; special sitting of the People's Courts are arranged; minors are not liable to the death penalty. See Hazard, op. cit. supra note 166 at 44.

171. Statistics on juvenile delinquency showed a marked correlation between juvenile delinquency and weak family life. See Hazard, op. cit. supra note 166 at 424-5.

172. See Boshko, The Conception of Marriage in Societ Socialist Family Law (1939) 1 Socialist Legality (in Russian) 54.

173. Demographic considerations are emphasized as one fundamental aspect of the interest of the State in family law by Sverdlov, On the Object and System of Socialist Family Lavo (1941) 1 Soviet STATE AND LAW 57, 61-3.

174. Custody questions were determined with greater regard to the predominant right of parents to bring up their children. Cases reported in 14 Soviet Justice (1939) (in Russian) 77 et seq. In the case of a youth who was treated badly by his step-mother, his father acquiescing, and who grew despondent and committed suicide, the step-mother, a teacher, was sentenced to five years' deprivation of liberty and deprived of the right to teach for five years thereafter, and the father, a doctor (a neuropathologist) was sentenced to two years deprivation of liberty, for the crime of bringing a minor to suicide. 12 SoviET JUSTICE (1941) (in Russian) 21. Ways were found to exact support for parents from daughters who did not have an independent wage but were dependent on their husbands, by levying on the daughter's share of the common property of her and her husband. Rabinovich, op. cil. supra note 155 , at 27 .

175. See pp. 40-1 supra.

176. The right to build one's own home is granted by contract with the local Soviet. The contract is in the form of a lease on the land-for 65 years for a brick or stone building, 50 years for a wood structure. Home builders are granted credits by the State Banl: and guaranteed the necessary materials, provided that they invest a minimum of 30 per cent of the total cost of the building. Such building loans are given for a maximum of 10,000 rubles and a seven year amortization. Interest is two per cent. In 1942, loans totalled 7,000,000 
insurance was restored. ${ }^{177}$ The law of succession has been broadened. ${ }^{178}$

The 1945 amendments to the Family Code are an enormous leap in the direction of state protection of mother and child. By them the Soviet state has assumed a considerable portion of the financial risk of having children. ${ }^{179}$ Mothers are granted allowances on the birth of the third and each subsequent child ${ }^{180}$ the privileges for expectant mothers

rubles; in 1943, 35,000,000; in 1944, 260,000,000; in 1945,325,000,000. 5 EMDASSY of TUle U.S.S.R. INForaration BulL., No. 98 (Sept. 22, 1945); id. No. 96 (Sept. 18, 1945).

"With the building of permanent houses, the trend is away from the big apartment

houses toward one- and two-story houses. . . . Even in Moscow, the new sections on the city's outskirts will consist of two-story flats, with two to four apartments on each floor. ... " Blumenfeld, The Soviel Housing Problem (Nov. 1945) AMerican Review on tuE SOVIET UNION 12, 24.

177. Life insurance was abolished Nov. 18, 1919. Coll. Laws, R.S.F.S.R. (1919) No. 56, Art. 542. But see advertisements of the State Insurance Trust (Gosstrakh) in the magazine ART AND LIFE, Oct. 9, 1943 (in Russian), inviting citizens to take out policies with the minimum premium fixed at 5,000 rubles.

178. Edict of June 12, 1945, On Changes of the Civil Code of the R.S.F.S.R. (July 12, 1945) JourNAL OF THE SUPREME SOvIET OF THE U.S.S.R., No. 38 (in Russian) 4, incorporating the Edict of the Presidium of the Supreme Soviet of the U.S.S.R. of March 14, 1945 into the Civil Code of the R.S.F.S.R. Under the new system of succession, there are three classes of heirs: 1) the children, surviving spouse, persons who have been entirely dependent on the decedent for a year preceding his death, and parents who are unable to earn; 2) able-bodicd parents; 3 ) brothers and sisters. In the absence of a will, the estate goes to the first class of heirs; if they are absent or if they refuse to take (in Russian law the heir, if he takes, must assume the obligations of the decedent as well), the estate goes to the second class; and if the members of the second class are absent or refuse to take, it goes to the third class. CIvIl CoDE, R.S.F.S.R., Art. 418 as amended. The property is still divided in equal shares, but now the grandchildren' and great-grandchildren inherit per stirpes. Id., Art. 421. All of the estate or part of it may be left by will to one or several of the persons who inherit by law, but the testator may not deprive his minor children and other heirs who are unable to earn of the share which would go to them by intestate succession. In the absence of any heirs the property may be left by will to any person. Id., Art. 422 as amended.

See note 155 supra for discussion of the law of inheritance prior to the changes of 1945 .

In 1943 the earlier inheritance taxes were repealed; the highest now clocs not exceed ten per cent. Law of the U.S.S.R., Inheritance, LAwYER'S DirECTORY (1946).

Recent judicial practice has in substance recognized that a person who receives an estate "for administration and disposition" possesses all the rights of owner of that property. This is a further extension of the rights of heirs, for otherwise the property would escheat. Serebrovski, History of the Development of Soviet Inheritance Law (1945) ACADEMY Or SCIENCE OF THE U.S.S.R., QUESTIONS OF Soviet Civin Law (in Russian) 156, 162.

179. In the first year after the promulgation of the Edict of July $8,1944,1,500,000,000$ rubles were paid out in State allowances to hundreds of thousands of mothers of large families and to unmarried mothers. The 1945 budget included 2,452,123,000 rubles for the protection of mother and child. Interview with People's Commissar for Health of the U.S.S.R. (July 26, 1945) 5 Embassy of the U.S.S.R. Information Bull., No. 75.

180. On the birth of the third child to a mother with two children, a single grant of 400 rubles is made. On the birth of a fourth child to a mother with three children, a single grant of 1300 rubles and a monthly allowance of 80 rubles. Fifth child: single grant of 1700 rubles and a monthly allowance of 120 rubles. Sixth child: single grant of 2000 rubles and monthly allowance of 140 rubles. Seventh or eighth child: 2500 rubles and allowance of 200 rubles. 
are considerably increased, ${ }^{181}$ and the network of institutions for the care of mothers and children is considerably extended. ${ }^{182}$ Part of the cost of the new program is met with an income tax on single men and women and on citizens with two children or less. ${ }^{183}$ The prohibition of abortions and the criminal sanction against "insulting and humiliating the dignity of mothers" are reaffirmed. ${ }^{184}$ And as a symbol of the value which the state places upon the bearing of children, the Motherhood Medal, the Order of the Glory of Motherhood, and the honorary title of Mother Heroine are instituted for mothers of five children and more. ${ }^{185}$

Ninth or 10th child: 3500 and 250. Eleventh and each succeeding child: 5000 and 300 . The monthly allowances are paid beginning with the second year of the child's life and continuing until the child reaches the age of 5. Edict of the Presidium of the Supreme Soviet of the U.S.S.R., July 8, 1944, Art. 2, published in 4 ErrassY of tHE U.S.S.R. IxForsutrox Butr., No. 84 (July 26,1944 ).

181. Maternity leaves for women factory workers and office employees are increased from 63 to 77 calendar days, and annual vacations must be timed to precede or follow maternity leave. Edict of July 8, 1944, cited supra note 180, Art. 6. After four months pregnancy, women are not to be given overtime work, and women with infants are to be exempted from night work throughout the period of nursing. Id., Art. 7. Food rations for expectant mothers and for nursing mothers are doubled. Id., Art. 8. Fees at lindergartens and nurseries are reduced by 50 per cent for the accommodation of children of parents with three children and with monthly earnings up to 400 rubles, with four children and with monthly earnings up to 600 rubles, with five or more children regardless of earnings. Id., Art. 10.

182. Additional mother and child centers, special rest homes for needy unmarried expectant mothers and for nursing mothers in poor health; additional children's institutions, medical consultation centers for children, milk kitchens, nurseries for infants, evening accommodations at kindergartens, maternity institutions in areas liberated from the German invaders; the obligatory organization at enterprises and institutions where vomen are employed in large numbers, of nurseries, kindergartens, and special rest rooms for nursing mothers; the considerable extension of the output of clothing and footwear for children, toilet accessories for children, etc., both for children's institutions and for $\lesssim$ le to the general public, are provided, Edict of July 8,1944, cited supro note 180, Art. 11.

183. The Edict of the Presidium of the Supreme Soviet of the U.S.S.R. of Nov. 21, 1941, "On the tax on single men and women and childless citizens of the U.S.S.R.," is modified. The tax is now levied on citizens who have no children and on citizens who have one or two children; for men over 20 and up to 50 and for women over 20 and up to 45 . Edict of July 8 , 1944, cited supra note 180, Art. 16. Citizens paying income tas are taxed to the extent of six per cent of their income if they have no children, one per cent if they have one child, and one-half per cent if they have two children. Farmers pay 150 rubles a year if they have no children, 50 if they have one, 25 if they have two. Other citizens pay 90 if they have no children, 30 if they have one, 15 if they have two. Id., Art. 17. Servicemen and their wives, students and invalids are exempted as are citizens whose children have been lilled or are missing on fronts of the Patriotic War. Id., Art. 18.

184. Id., Art. 31.

185. The Motherhood Medal, First and Second Class, is awarded to mothers who have given birth to and reared six and five children respectively. The Order of Glory of Motherhood, First, Second and Third Class, is awarded to mothers who have given birth to and reared nine, eight, and seven children respectively. The title of Mother Heroine is conferred on mothers who have given birth to and reared ten children, the avard being accompanied 
Here again a fundamental principle- the protection of mother and child by the state-is restated and redirected toward the security of the family and the home.

It has been seen that the new Soviet family legislation is the culmination of a trend toward the strengthening of the bonds between the family and the state and the bonds between the family members themselves. The Soviet lawmakers have been able to preserve certain Revolutionary principles by placing them under the aegis of law and redirecting them to meet the needs of family security. Through compulsory registration of marriage, the principle of monogamy which earlier Soviet theorists had hoped would be realized by the free choice of individuals, is now enforced by the state. In restoring divorce to the jurisdiction of the courts and in making it difficult to obtain, the new law helps to preserve the lifelong character of marriage which was threatened by the frivolous attitude that had developed toward de facto marriage and de facto divorce. The legal equality of the spouses, formerly a principle tending to take the woman out of the home, is now extended to reinforce her position as wife (through new judicial interpretation of the community property law) and mother (through the institution of family benefits on a large scale to the mothers of large families). Children born out of wedlock are not treated as "illegitimate," though for the purpose of distinguishing more clearly between marital and extra-marital ties, they are now supported by state funds rather than by allowances from their fathers. Finally, mother and child are given the protection of the state not simply through social institutions but chiefly in the home through the payment of family benefits.

Yet in invoking law in the interests of family stability, a profound transformation of the philosophy of the Revolution has been effected. The Marxist conception of marriage as based primarily on the satisfaction of natural needs, and of the family as historically relative and economically determined, has not sufficed to support enduring marriages and strong family life. A revaluation of personal values has been found essential. Marriage and the family have come to be conceived as the fulfilment of spiritual requirements of human personality, and the law as a necessary means of protecting such requirements. ${ }^{180}$

by the presentation of the Order of Mother Heroine and a scroll from the Presidium of the Supreme Soviet of the U.S.S.R.

Over 750,000 mothers were awarded "Glory of Motherhood" orders and 5,850 women received the title "Mother Heroine" between July, 1944 and March, 1946. 6 EMDASSY or THE U.S.S.R. INFORMATION BulL. (March 12, 1946) 203.

186. See Volfson, Family LaW (1938) (in Russian) 3, "Concern for human personality comprises the central subject of our family law." Particularly in regard to motherhood, Saviet literature stresses the psychological features, as well as the sociological, of the now 
Herein Soviet jurists have found a link with the pre-revolutionary Russian heritage.

The family legislation of 1944 and 1945 is thus an indication that in the restoration of law which is now in full swing in the Soviet Union, ways will be found to reconcile Marxist revolutionary ideals with the traditions of the Russian past.

values. See Pravda (in Russian), July 8, 1944, in welcoming the new legislation on family benefits: "There is no greater happiness in nature than the happiness of being a mother. This is an inexhaustible source of human joy. A woman who has not yet lnown the joy of motherhood has not yet realized all the greatness of her calling. The lnowledge that her children will be taking part in great creative work, that they will be creators and builders of the new Socialist life, will bear new ideas and live in a new way, fills every Soviet woman with pride. It is the greatest stimulus to the care of the family, of the children, and for their upbringing." 